\title{
Identification of genes differentially expressed in a resistant reaction to Mycosphaerella pinodes in pea using microarray technology
}

\author{
Sara Fondevilla', Helge Küster ${ }^{2}$, Franziska Krajinski ${ }^{3}$, José I Cubero', Diego Rubiales ${ }^{4 *}$
}

\begin{abstract}
Background: Ascochyta blight, caused by Mycosphaerella pinodes is one of the most important pea pathogens. However, little is known about the genes and mechanisms of resistance acting against $M$. pinodes in pea. Resistance identified so far to this pathogen is incomplete, polygenic and scarce in pea, being most common in Pisum relatives. The identification of the genes underlying resistance would increase our knowledge about M. pinodes-pea interaction and would facilitate the introgression of resistance into pea varieties. In the present study differentially expressed genes in the resistant P. sativum ssp. syriacum accession P665 comparing to the susceptible pea cv. Messire after inoculation with M. pinodes have been identified using a M. truncatula microarray.

Results: Of the 16,470 sequences analysed, 346 were differentially regulated. Differentially regulated genes belonged to almost all functional categories and included genes involved in defense such as genes involved in cell wall reinforcement, phenylpropanoid and phytoalexins metabolism, pathogenesis- related (PR) proteins and detoxification processes. Genes associated with jasmonic acid (JA) and ethylene signal transduction pathways were induced suggesting that the response to $M$. pinodes in pea is regulated via JA and ET pathways. Expression levels of ten differentially regulated genes were validated in inoculated and control plants using QRT-PCR showing that the P665 accession shows constitutively an increased expression of the defense related genes as peroxidases, disease resistance response protein 39 (DRR230-b), glutathione S-transferase (GST) and 6a-hydroxymaackiain methyltransferase.

Conclusions: Through this study a global view of genes expressed during resistance to $M$. pinodes has been obtained, giving relevant information about the mechanisms and pathways conferring resistance to this important disease. In addition, the $M$. truncatula microarray represents an efficient tool to identify candidate genes controlling resistance to $M$. pinodes in pea.
\end{abstract}

\section{Background}

Legumes are a versatile and inexpensive source of protein for human food and animal feed. In addition, legumes provide numerous environmental benefits that could contribute to the sustainability of agriculture. Legumes are able to symbiotically fix atmospheric nitrogen, improving soil fertility and decreasing $\mathrm{N}$ fertilizers needs [1].

Dry pea is the most produced legume in Europe and the fourth most in the world [2] and one of the most

\footnotetext{
* Correspondence: diego.rubiales@ias.csic.es

${ }^{4}$ CSIC, Institute for Sustainable Agriculture, Apdo. 4084, E-14080,Córdoba, Spain

Full list of author information is available at the end of the article
}

productive. However, the instability of pea yields, caused mainly by the occurrence of diseases, hampers the expansion of this legume.

Ascochyta blight, caused by Mycosphaerella pinodes (Berk \& Blox) Vesterg, the teleomorph of Ascochyta pinodes (Berk \& Blox) Jones, is one of the most important pea pathogens [3]. It is widespread throughout the major pea growing areas $[4,5]$, especially in temperate regions of Europe, North America, Australia and New Zealand [4] and constitutes the major constraint for the crop after broomrape in the Mediterranean basin [6]. The disease causes $10 \%$ yield losses as an average and can reach $50 \%$ under some conditions [7]. The use of resistant varieties would be the most efficient,
C Biomed Central

(c) 2011 Fondevilla et al; licensee BioMed Central Ltd. This is an Open Access article distributed under the terms of the Creative Commons Attribution License (http://creativecommons.org/licenses/by/2.0), which permits unrestricted use, distribution, and reproduction in any medium, provided the original work is properly cited. 
economical and ecologically strategy to control the disease. However, pea varieties resistant to $M$. pinodes are not available.

Complete resistance to $M$. pinodes has not been identified so far. Although extensive searches have been carried out, only moderate resistance has been reported in the cultivated pea [8-10] and this has been inadequate to control the disease. Higher levels of resistance have been identified in wild species of Pisum [8,11,12], but their use in breeding programs is hampered by the polygenic nature of resistance.

The identification of the genes controlling resistance to $M$. pinodes in these wild resistant accessions would facilitate their introgression into pea varieties but these genes are difficult to identify by traditional approaches. Quantitative Trait Loci (QTL) analysis have identified numerous genomic regions involved in resistance to this disease in pea [13-17]. In addition, candidate genes approaches and comparative mapping have revealed the co-localization of QTLs for resistance to $M$. pinodes and resistance gene analogs, the putative transcription factor PsDof1 and the pea defensin DRR230-b $[18,16]$, but still very little is known about the mechanisms of response to $M$. pinodes in pea at the histological, molecular and biochemical level.

Large scale expression studies would allow the establishment of a global and detailed picture of all genes and metabolic pathways expressed or differentially regulated during $M$. pinodes-pea interaction and would contribute to the identification of candidate genes implicated in ascochyta blight resistance. However, this approach has never been performed in this pathosystem.

The goal of this study was to identify genes and mechanisms of resistance underlying phenotypic variation in resistance to $M$. pinodes in pea using microarray technology. The advent of microarray technology has enabled large-scale surveys leading to a more integrated view of gene expression responses [19]. In plant-pathogen interactions microarray studies allow a more comprehensive understanding of molecular responses in the infection process making the elucidation of mechanisms involved in resistance possible [20]. The microarray technology requires prior knowledge of the sequence of the genome, but sequence information of pea is at the moment limited. Therefore, this study has taken advantage of the knowledge and tools developed in the model legume Medicago truncatula. A microarray (Mt16KOLI1Plus) [21] containing 16,470 different 70 mer oligonucleotides from $M$. truncatula, that represent all tentative consensus sequences (TCs) of the TIGR $M$. truncatula Gene Index 5 (http://compbio.dfci.harvard. edu/tgi/cgi-bin/tgi/gimain.pl?gudb=medicago) is available. In the present study cDNA obtained from resistant and susceptible pea plants inoculated with $M$. pinodes has been hybridised to this microarray and genes differentially expressed in the resistant genotype during $M$. pinodes infection have been identified.

\section{Results}

\section{Microarray experiment}

Of the 16,470 sequences included in the microarray, only 25 did not show an analizable signal in any of the time points studied and the vast majority of them showed an analyzable signal in all the time points included. Of the sequences analysed, 346 were significantly differentially regulated in P665 compared to Messire in at least one time point $(M \geq 0.8$ or $M \leq-0.8, p \leq$ $0.05)$. A complete list of these genes is included in Additional file 1, Table S1. Of them, around 70\% showed sequences similarities to existing sequence entries of known function in the databases. The remaining (30\%) represented sequences of currently unknown functions (Figure 1). Genes differentially regulated belonged to almost all functional categories described by Journet et al. [22]. In the case of genes with higher transcript levels in P665 than in Messire (called up-regulated in this paper), the largest proportion belonged to the category 'Defense and cell rescue' (16,1\%), followed by 'Primary metabolism' (13.9\%). Genes included in the categories 'Secondary metabolism and hormone metabolism' (9.5\%) and 'Gene expression and RNA metabolism' (8.8\%) were also abundant. Categories 'Miscellaneous' (5.8\%), 'Membrane transport' (3.6\%), 'Cell Wall', 'Protein synthesis and processing', and 'Signal transduction and posttranslational regulation' (around 2.9\% each) were also present. Only one gene of the category 'Chromatin and DNA metabolism' was up regulated and none in the categories 'Cytoskeleton' and 'Vesicular trafficking, secretion and protein sorting'.

In the case of genes less expressed in P665 than in Messire (called down-regulated), the most abundant category was 'Primary metabolism' (25.5\%). Categories 'Signal transduction and post-translational regulation', 'Gene expression and RNA metabolism', 'Defense and cell rescue' and 'Cell Wall' formed a second group representing around 6\% each. The percentage of genes included in the categories 'Protein synthesis and processing', 'Secondary metabolism and hormone metabolism', 'Membrane transport' or not classified in any category, ranged from 2.9 to 4.4 while the remaining categories were weakly represented.

The up regulation of genes belonging to the functional categories 'Defense and cell rescue' and 'Secondary metabolism and hormone metabolism' and the down regulation of genes involved in 'Primary metabolism' in P665 infected plants comparing to Messire was confirmed by the statistically significant higher percentage of differentially expressed genes included in these 


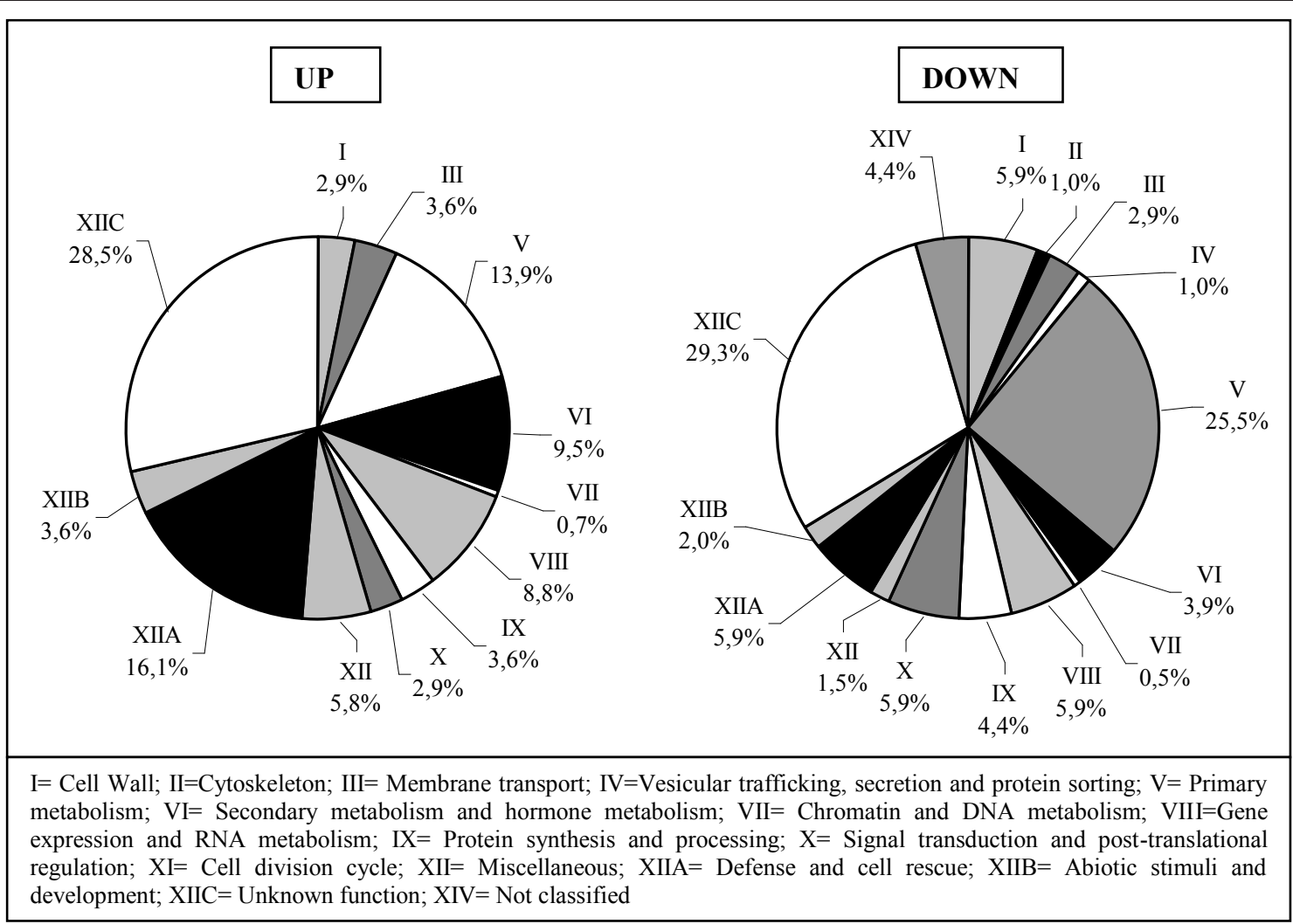

Figure 1 Functional classification of genes differentially regulated in P665, comparing to Messire, after inoculation with M. pinodes. Functional classification according to Journet et al. [22]) of genes up or down regulated in accession P665, comparing to Messire, after inoculation with $M$. pinodes. A gene was considered to be up/down regulated when $M \geq 0.8 / M \leq-0.8$ and $p \leq 0.05$ in at least one time point.

categories compared to the percentage of genes in these functional categories for which there was analyzable signal on the array (Figure 2). The category miscellaneus also showed some grade of up regulation. In contrast, a certain depletion was identified in the set of up regulated genes for the categories 'Protein synthesis and processing' and 'Signal transduction and post-translational regulation' and in the set of down regulated genes for the categories 'Gene expression and RNA metabolism' and' Protein synthesis and processing'.

The genes differentially regulated in P665 comparing to Messire belonging to the categories: 'Cell wall', 'Secondary metabolism and hormone metabolism', 'Gene expression and RNA metabolism', 'Signal transduction and post-translational regulation', 'Defense and cell rescue' and 'Abiotic stimuli and development' are shown in Table 1.

\section{Cell wall}

Sixteen sequences involved in cell wall were differentially expressed in inoculated P665 plants comparing to Messire. Genes implicated in cell wall reinforcement were in general more expressed in P665 than in Messire while genes involved in cell elongation, wall expansion and wall degradation were less expressed.

\section{Membrane transport}

Up-regulated genes belonging to this category included those associated with protein and amino acid transport and a putative $\mathrm{Na}+/ \mathrm{H}+$ antiporter. In contrast, several putative membrane transporter proteins and a gene involved in potassium transport were down regulated.

\section{Primary metabolism}

A high percentage of genes differentially expressed in P665 comparing to Messire corresponded to genes involved in primary metabolism. Most of them (73\%) showed down regulation. Of them, numerous sequences corresponded to genes participating in photosynthesis. Other down-regulated genes of this category were involved in mobilization and degradation of carbohydrates, degradation of storage oil and nitrogen metabolism. Interestingly, two sequences encoding NADHplastoquinone oxidoreductase chain 1 chloroplast were also down regulated.

Genes up-regulated included glucosyltransferases, a probable anthocyanin 5-aromatic acyltransferase, a 


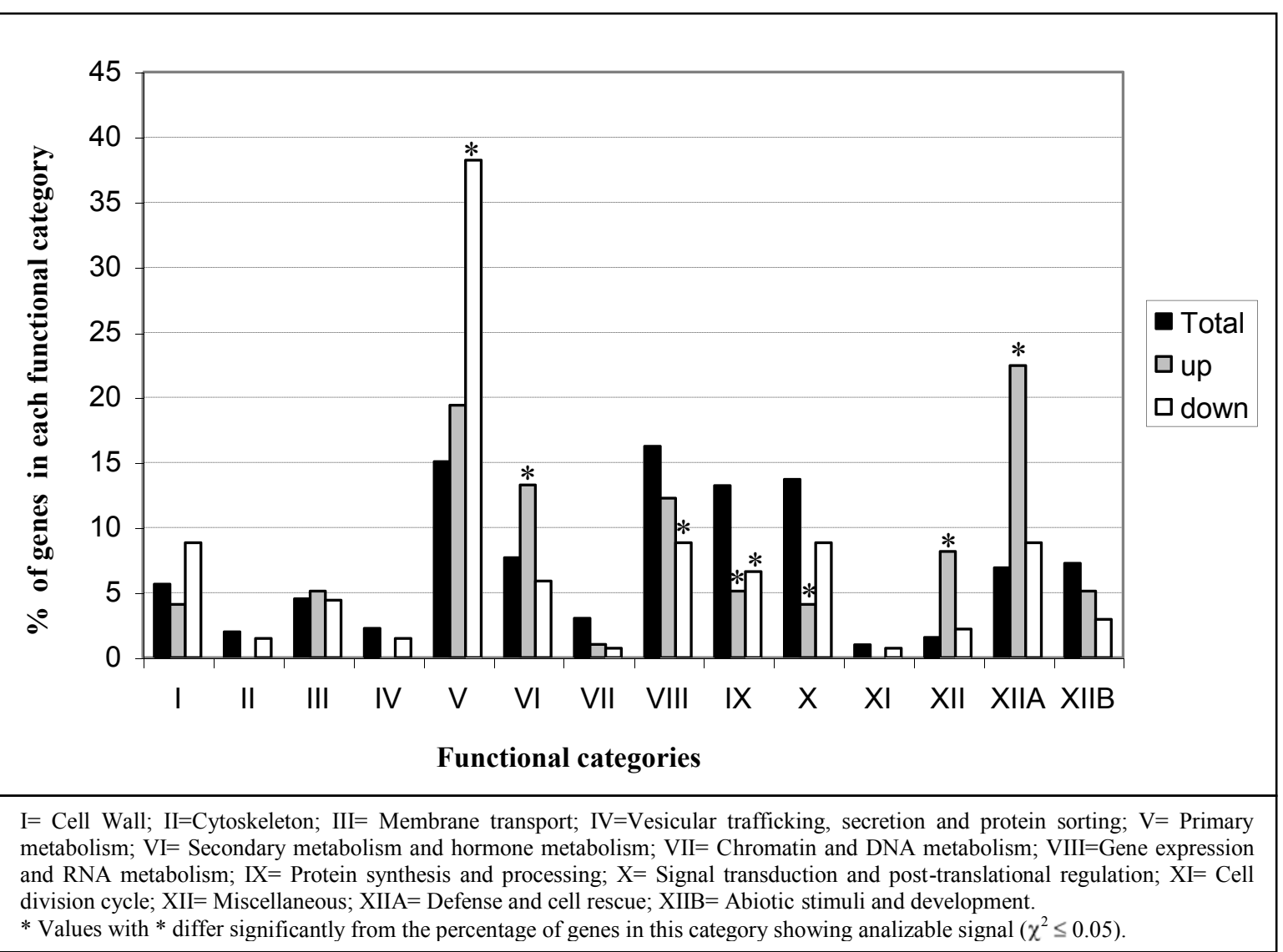

Figure 2 Functional classification of genes showing analysable signal compared to up/down regulated genes. Percentage of genes in each functional category for which there was analyzable signal on the array (Total) compared to the percentage of up/down regulated genes in each category. Genes with unknown function or that could not be classified in any category were not included in the analysis.

putative acid phosphatase and genes involved in amino acid and phosphor metabolism.

\section{Secondary metabolism and hormone metabolism}

The secondary metabolism plays an important role in the response against pathogens. Several genes associated with the synthesis of antimicrobial compounds and involved in defense were more expressed in P665 compared to Messire after inoculation with $M$. pinodes. Among them, genes involved in phenylpropanoid, alkaloid and flavonoid metabolism, a sequence encoding phenylalanine ammonia-lyase, 2 sequences encoding lipoxygenases and genes involved in $\mathrm{H}_{2} \mathrm{O}_{2}$ production were included. However, a sequence showing similarities with a lipoxygenase, another encoding tropinone reductase homolog and a flavonol synthase-like protein were down regulated.

\section{Gene expression and RNA metabolism}

Several transcription factors and binding proteins were differentially regulated in P665 comparing to Messire. Genes up regulated encoded a NAC domain protein, an ethylene responsive element binding factor and transcriptions factors belonging to ERF and GRAS families. Transcription factors belonging to bHLH and GATA family were down regulated.

\section{Signal transduction and post-translational regulation}

Interestingly, two sequences encoding a 12-oxophytodienoate reductase (OPR2) were more expressed in P665 than in Messire. Several protein kinases involved in different processes were less expressed.

\section{Miscellaneous}

Eleven sequences included in the 'Miscellaneous' category, according to Journet et al. [22] showed a different regulation in P665 compared to Messire. Among them there were three up-regulated sequences encoding lectins, proteins that can be involved in defense. Other upregulated genes encoded a beta-glucosidase and an early light inducible protein. A CLC-b chloride channel protein was down regulated. Genes similar to dermal glycoproteins and a legumin were represented by different sequences that were up-regulated in some cases and down regulated in others. 
Table 1 Most relevant genes differentially expressed in P665 compared to Messire after inoculation with M. pinodes

\begin{tabular}{|c|c|c|c|c|c|c|}
\hline Oligo ID ${ }^{a}$ & TIGR ID & Annotation & M16 & M24 & M48 & FC \\
\hline MT015143 & BG584806 & Repetitive proline-rich cell wall protein 2 precursor & $1.39^{*}$ & $1.04^{*}$ & $1.30^{*}$ & I \\
\hline MT015121 & BG586912 & Repetitive proline-rich cell wall protein 1 precursor & $1.22^{*}$ & 0.69 & $1.05^{*}$ & 1 \\
\hline MT002297 & TC79657 & Nodulin-like protein & $1.19^{*}$ & $0.86^{*}$ & $0.86^{*}$ & I \\
\hline MT005666 & TC83381 & Caffeic acid O-methyltransferase & 0.17 & 0.22 & $0.88^{*}$ & I \\
\hline MT004103 & TC82015 & Beta-galactosidase & 0.03 & -0.08 & $-1.13^{*}$ & 1 \\
\hline MT014461 & TC86053 & Beta-galactosidase & -0.18 & -0.40 & $-1.23^{*}$ & 1 \\
\hline MT013510 & TC91374 & Probable xyloglucan endotransglycosylase & -0.44 & $-1.08^{*}$ & -0.61 & 1 \\
\hline MT006437 & TC77501 & Endoxyloglucan transferase & -0.71 & 0.12 & -1.42 & I \\
\hline MT014283 & TC85611 & Caffeoyl-CoA O-methyltransferase & $-0.87^{*}$ & -0.12 & $-1.55^{*}$ & 1 \\
\hline MT014301 & TC76880 & Endoxyloglucan transferase & $-0.90^{*}$ & 0.08 & -0.51 & 1 \\
\hline MT014287 & TC76828 & Extensin-like protein & $-1.00^{*}$ & 0.12 & -0.43 & 1 \\
\hline MT001416 & TC78670 & Expansin & $-1.01^{*}$ & 0.31 & 0.19 & 1 \\
\hline MT014300 & BQ136812 & Xyloglucan endotransglycosylase & $-1.05^{*}$ & 0.15 & $-0.82^{*}$ & I \\
\hline MT015434 & TC86491 & Expansin & $-1.09^{*}$ & -0.44 & $-1.21^{*}$ & 1 \\
\hline MT009043 & TC78936 & Protein $\mathrm{T} 10 \mathrm{O} 24.17$ & $-1.14^{*}$ & $-1.38^{*}$ & $-1.06^{*}$ & I \\
\hline MT007149 & TC76727 & Putative proline-rich protein APG isolog & $-1.49^{*}$ & $-0.81^{*}$ & -0.45 & I \\
\hline МT015061 & TC85201 & Lipoxygenase & $1.42^{*}$ & $0.88^{*}$ & 0.44 & $\mathrm{Vl}$ \\
\hline MT013322 & TC93346 & Peroxisomal copper-containing amine oxidase & $0.99^{*}$ & 0.27 & 0.02 & $\mathrm{Vl}$ \\
\hline MT006064 & TC91378 & AT3g62110 & $0.95^{*}$ & $0.85^{*}$ & 0.67 & $\mathrm{Vl}$ \\
\hline MT000596 & TC86308 & Cytochrome P450 78A3 & 0.74 & -0.71 & $-1.90^{*}$ & $\mathrm{Vl}$ \\
\hline MT005593 & TC83534 & Putative amine oxidase & 0.57 & -0.14 & $1.46^{*}$ & $\mathrm{Vl}$ \\
\hline MT001070 & TC78077 & UDP-glycose flavonoid glycosyltransferase & 0.57 & $0.85^{*}$ & 0.20 & $\mathrm{Vl}$ \\
\hline MT006134 & TC81027 & 4-coumarate-CoA ligase-like protein & 0.38 & $1.37^{*}$ & 0.1 & $\mathrm{Vl}$ \\
\hline MT006994 & TC85176 & Lipoxygenase & 0.32 & 0.25 & $-1.54^{*}$ & $\mathrm{Vl}$ \\
\hline MT000200 & TC85619 & Probable lipoxygenase & 0.17 & 0.07 & $0.86^{*}$ & $\mathrm{Vl}$ \\
\hline MT000193 & TC85559 & Acetyl-CoA carboxylase & 0.13 & $1.34^{*}$ & 0.06 & $\mathrm{Vl}$ \\
\hline MT000333 & TC85502 & Phenylalanine ammonia-lyase & 0.06 & $1.32^{*}$ & -0.44 & $\mathrm{Vl}$ \\
\hline MT013671 & TC84229 & Cytochrome p450 & 0.06 & -0.66 & $-0.87^{*}$ & $\mathrm{Vl}$ \\
\hline MT012159 & TC83702 & Squalene monooxygenase & 0.05 & $0.94^{*}$ & -0.47 & $\mathrm{Vl}$ \\
\hline MT003115 & TC89052 & Cytochrome P-450LXXIA1 (cyp71A1) & 0.05 & 0.21 & $1.23^{*}$ & $\mathrm{Vl}$ \\
\hline МT001043 & TC77410 & Flavanone 3 beta-hydroxylase & 0.02 & 0.15 & $1.49^{*}$ & $\mathrm{Vl}$ \\
\hline MT002497 & TC88443 & Hyoscyamine 6 beta-hydroxylase & -0.13 & 0.53 & $0.96^{*}$ & $\mathrm{Vl}$ \\
\hline MT009587 & TC78460 & Flavonol synthase-like protein & $-0.81^{*}$ & -0.42 & -0.47 & $\mathrm{Vl}$ \\
\hline MT003010 & TC89135 & Cytochrome P450 71A21 & $-1.06^{*}$ & $-2.15^{*}$ & -0.37 & $\mathrm{Vl}$ \\
\hline MT014118 & TC85168 & Lipoxygenase & $-1.48^{*}$ & $-1.73^{*}$ & 0.24 & $\mathrm{Vl}$ \\
\hline MT002785 & TC80364 & Tropinone reductase homolog & $-1.32^{*}$ & $-1.40^{*}$ & $-1.53^{*}$ & $\mathrm{Vl}$ \\
\hline MT012682 & TC80051 & Amygdalin hydrolase isoform $\mathrm{AH}$ I precursor & $-1.39^{*}$ & -0.48 & -0.45 & $\mathrm{Vl}$ \\
\hline MT001339 & TC87447 & NAC domain protein NAC1 & $1.26^{*}$ & $1.11^{*}$ & 0.28 & VIII \\
\hline MT009598 & TC79845 & Ethylene responsive element binding factor-like & $1.09^{*}$ & $1.43^{*}$ & 0.39 & VIII \\
\hline MT008649 & TC87796 & EBNA-1 nuclear protein & $1.06^{*}$ & $1.00^{*}$ & 0.60 & VIII \\
\hline MT005976 & TC93710 & Promoter-binding factor-like protein & $1.03^{*}$ & $0.91^{*}$ & 0.80 & VIII \\
\hline MT000362 & TC77110 & Putative steroid membrane binding protein & $1.01^{*}$ & $1.01^{*}$ & $1.17^{*}$ & VIII \\
\hline MT016167 & BI262875 & GRAS family transcription factor & $0.90^{*}$ & 0.66 & 0.13 & VIII \\
\hline MT015261 & TC76796 & Transcription factor JERF1 & $0.89^{*}$ & $0.97^{*}$ & 0.29 & VIII \\
\hline MT016157 & BE319790 & Pathogenesis related transcriptional factor and ERF & $0.88^{*}$ & 0.02 & -0.29 & VIII \\
\hline MT002827 & TC80713 & Probable cysteinyl-tRNA synthetase & $0.86^{*}$ & $0.83^{*}$ & 0.38 & VIII \\
\hline MT008661 & TC87393 & Probable CCCH-type zinc finger protein & $0.85^{*}$ & 0.24 & -0.27 & VIII \\
\hline MT016437 & AJ848040 & Probable $\mathrm{C} 2 \mathrm{H} 2$ type zinc finger protein ID1 like & 0.33 & $0.86^{*}$ & -0.13 & VIII \\
\hline MT011589 & TC87048 & 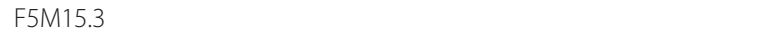 & -0.07 & $-1.13^{*}$ & $-1.98^{*}$ & VIII \\
\hline MT008378 & TC87360 & Chromosome chr7 scaffold_31 whole genome shotgun sequence & -0.19 & -0.15 & $-0.83^{*}$ & VIII \\
\hline MT008731 & TC78273 & Putative transcription factor APFI & -0.31 & $-0.88^{*}$ & -0.13 & VIII \\
\hline
\end{tabular}


Table 1 Most relevant genes differentially expressed in P665 compared to Messire after inoculation with M. pinodes (Continued)

\begin{tabular}{|c|c|c|c|c|c|c|}
\hline MT015990 & TC76565 & AT3g16857 & -0.40 & $-1.41^{*}$ & -0.50 & VIII \\
\hline MT013325 & TC84058 & GATA-binding transcription factor-like protein & -0.52 & -0.39 & $-1.09^{*}$ & VIIII \\
\hline MT009202 & TC77895 & AT4g00150 & -0.58 & 0.48 & $1.51^{*}$ & VIII \\
\hline MT011704 & TC91195 & Putative CTP synthase & $-0.81^{*}$ & $-0.81^{*}$ & $-0.66^{*}$ & VIIII \\
\hline MT002341 & TC79766 & bHLH transcription factor GBOF-1 & $-0.84^{*}$ & -0.13 & 0.18 & VIIII \\
\hline МT011401 & TC79757 & AT3g09731 & $-1.03^{*}$ & -0.61 & -0.59 & VIII \\
\hline MT015283 & TC85653 & SRG1 protein & $-1.12^{*}$ & -0.05 & 0.15 & VIII \\
\hline МT015124 & AL371197 & Glycine-rich RNA binding protein & $-1.30^{*}$ & -0.61 & -0.28 & VIII \\
\hline MT011927 & TC90604 & Probable homeobox protein T9L24.43 & -1.47 & -0.11 & 0.22 & VIIII \\
\hline МT012751 & TC83617 & Transcriptional regulator AraC family & $-1.69^{*}$ & $-0.94^{*}$ & -1.32 & VIII \\
\hline MT014356 & TC85808 & 12-oxophytodienoate reductase (OPR2) & $1.27^{*}$ & $1.06^{*}$ & 0.03 & $x$ \\
\hline MT014354 & TC85808 & 12-oxophytodienoate reductase (OPR2) & $1.19^{*}$ & 0.71 & -0.25 & $x$ \\
\hline MT011343 & TC80935 & Receptor protein-like & $1.15^{*}$ & $0.88^{*}$ & 0.03 & $x$ \\
\hline МT011648 & TC91194 & Putative wall associated serine/theorine kinase & $0.81^{*}$ & -0.01 & 0.39 & $x$ \\
\hline MT002252 & TC87949 & Calcium/calmodulin-dependent protein kinase CaMK2 & 0.06 & -0.20 & $-0.91^{*}$ & $x$ \\
\hline MT002729 & TC89621 & At2g23450 & 0.04 & -0.18 & $-1.07^{*}$ & $x$ \\
\hline МT009158 & TC88304 & F12A21.14 & -0.10 & $-1.28^{*}$ & -0.40 & $x$ \\
\hline MT014753 & TC90240 & Ser/Thr kinase & -0.15 & 0.48 & $-1.38^{*}$ & $x$ \\
\hline MT013890 & TC88105 & Putative protein kinase & -0.23 & -0.17 & $-0.98^{*}$ & $x$ \\
\hline MT008763 & TC79044 & Protein kinase & -0.40 & 0.44 & $-1.00^{*}$ & $x$ \\
\hline MT010193 & TC80761 & RAB1Y & -0.73 & $-2.25^{*}$ & -0.76 & $x$ \\
\hline MT015663 & TC88029 & Signal peptidase & $-0.83^{*}$ & -0.80 & -0.47 & $x$ \\
\hline MT008494 & TC78698 & Signal recognition particle $54 \mathrm{kDa}$ subunit precursor & $-0.88^{*}$ & -0.58 & $-1.13^{*}$ & $x$ \\
\hline МT009940 & BI263421 & Mitogen-activated protein kinase & $-1.39^{*}$ & $-0.87^{*}$ & $-1.12^{*}$ & $x$ \\
\hline MT012718 & TC83265 & Guanylate kinase & $-1.85^{*}$ & -0.22 & -0.29 & $x$ \\
\hline MT010223 & TC90306 & At1g21410 & $-1.86^{*}$ & 0.13 & 0.77 & $x$ \\
\hline МT014704 & TC80412 & Peroxidase & $3.61^{*}$ & $3.08^{*}$ & $1.56^{*}$ & XIIA \\
\hline МT001261 & TC87286 & Nine-cis-epoxycarotenoid dioxygenase4 & $2.06^{*}$ & $1.68^{*}$ & -0.05 & XIIA \\
\hline MT015019 & TC93000 & Bacterial-induced peroxidase precursor & $1.97^{*}$ & $1.32^{*}$ & $1.02^{*}$ & XIIA \\
\hline MT014726 & TC79559 & Glutathione S-transferase & $1.96^{*}$ & $2.08^{*}$ & - & XIIA \\
\hline MT008551 & TC78940 & Cationic peroxidase 2 precursor & $1.77^{*}$ & $1.20^{*}$ & -0.28 & XIIA \\
\hline MT012181 & C89099 & Lipid transfer protein SDi-9 drought-induced & $1.60^{*}$ & $1.20^{*}$ & $1.23^{*}$ & XIIA \\
\hline MT008366 & TC78224 & Bacterial-induced peroxidase precursor & $1.50^{*}$ & $1.77^{*}$ & $0.98^{*}$ & XIIA \\
\hline MT000911 & TC76930 & Syringolide-induced protein B13-1-9 & $1.38^{*}$ & $1.13^{*}$ & $1.00^{*}$ & $X I I A$ \\
\hline MT006316 & TC82368 & Disease resistance response protein 39 precursor & $1.29^{*}$ & $1.49^{*}$ & $1.13^{*}$ & XIIA \\
\hline MT006497 & TC93816 & $\mathrm{ABC}$ transporter & $1.29^{*}$ & $1.24^{*}$ & $1.10^{*}$ & XIIA \\
\hline МT006999 & TC85204 & Peroxidase1A & $1.28^{*}$ & $1.60^{*}$ & $1.81^{*}$ & XIIA \\
\hline MT007682 & TC77455 & Nine-cis-epoxycarotenoid dioxygenase 1 & $1.12^{*}$ & $1.09^{*}$ & $0.88^{*}$ & XIIA \\
\hline МT015903 & TC82203 & Peroxidase & $1.01^{*}$ & 0.76 & 0.39 & XIIA \\
\hline МT015524 & TC77937 & CjMDR1 & $0.98^{*}$ & 0.61 & 0.15 & XIIA \\
\hline MT014728 & TC78224 & Bacterial-induced peroxidase precursor & $0.91^{*}$ & 0.69 & 0.33 & $\mathrm{XIIA}$ \\
\hline МT015980 & TC82138 & Probable glutathione S-transferase & $0.86^{*}$ & 0.71 & 0.36 & XIIA \\
\hline МT009791 & TC86798 & Cyanogenic Beta-Glucosidase Molid 1 & $0.80^{*}$ & 0.14 & -0.24 & XIIA \\
\hline MT015051 & TC85153 & Peroxidase precursor & 0.48 & $0.98^{*}$ & $1.11^{*}$ & XIIA \\
\hline МT015067 & TC85170 & Peroxidase & 0.37 & $0.85^{*}$ & $1.17^{*}$ & $\mathrm{XIIA}$ \\
\hline MT014072 & TC77400 & Beta-1 3-glucanase & 0.13 & 0.41 & $-1.35^{*}$ & XIIA \\
\hline MT007613 & TC86304 & GA protein & 0.10 & 0.10 & $-2.28^{*}$ & XIIA \\
\hline MT014080 & TC85172 & Peroxidase 3 & 0.04 & $0.96^{*}$ & 0.01 & XIIA \\
\hline МT015763 & TC81227 & Elicitor inducible gene product Nt-SubE80 & 0.03 & -0.16 & $-0.87^{*}$ & XIIA \\
\hline MT015058 & TC85182 & Peroxidase & -0.35 & 0.65 & $-1.17^{*}$ & XIIA \\
\hline MT006425 & MT006425 & Disease resistance protein-like & -0.39 & -0.01 & $0.89^{*}$ & XIIA \\
\hline
\end{tabular}


Table 1 Most relevant genes differentially expressed in P665 compared to Messire after inoculation with M. pinodes (Continued)

\begin{tabular}{|c|c|c|c|c|c|c|}
\hline MT014328 & TC85843 & 5-epi-aristolochene synthase & -0.44 & -0.11 & $0.81^{*}$ & $X I I A$ \\
\hline MT014169 & TC76642 & Pprg2 protein & -0.72 & $-1.04^{*}$ & -0.38 & $X I I A$ \\
\hline МТ008899 & TC79452 & TIR-similar-domain-containing protein TSDC & -0.79 & $-1.10^{*}$ & $-1.62^{*}$ & XIIA \\
\hline MT000053 & BM813626 & Ascorbate peroxidase & $-0.90^{*}$ & -0.78 & -0.42 & $X I I A$ \\
\hline MT011658 & TC82236 & Putative resistance protein & $-1.18^{*}$ & -0.68 & $-3.38^{*}$ & $X I I A$ \\
\hline MT015567 & TC78525 & Syringolide-induced protein 19-1-5 & $-1.32^{*}$ & $-0.81^{*}$ & -0.39 & $X I I A$ \\
\hline MT000707 & TC86358 & 6a-hydroxymaackiain methyltransferase & $-2.13^{*}$ & $-1.98^{*}$ & $-1.71^{*}$ & $X I I A$ \\
\hline MT015446 & TC77584 & Epoxide hydrolase homolog & -3.48 & -0.40 & $-1.21^{*}$ & $X I I A$ \\
\hline MT015286 & TC85739 & Ripening-related protein-like & $1.66^{*}$ & $0.84^{*}$ & -0.16 & $\mathrm{XIIB}$ \\
\hline MT015373 & TC85963 & CIC protein cold-inducible & $1.65^{*}$ & $0.98^{*}$ & $1.00^{*}$ & $\mathrm{XIIB}$ \\
\hline MT003152 & TC88482 & Auxin influx carrier protein & $1.50^{*}$ & $1.19^{*}$ & $1.17^{*}$ & $\mathrm{XIIB}$ \\
\hline MT009872 & TC80360 & Probable wound-induced protein T9A4.6 & $0.94^{*}$ & 0.62 & -0.09 & $X I I B$ \\
\hline MT001051 & TC78061 & Auxin-induced protein & 0.68 & 0.63 & $-0.87^{*}$ & $\mathrm{XIIB}$ \\
\hline MT013626 & TC82806 & GMFP7 & -0.70 & -0.43 & $-0.83^{*}$ & $X I I B$ \\
\hline MT014513 & TC78341 & Embryo-specific protein-like & $-1.08^{*}$ & -0.10 & -0.54 & $X I I B$ \\
\hline МТ001024 & TC79562 & Putative $16.9 \mathrm{kDa}$ heat shock protein & $-1.12^{*}$ & -0.22 & $-1.04^{*}$ & $\mathrm{XIIB}$ \\
\hline
\end{tabular}

${ }^{a}$ Oligo ID, identifier of $M$. truncatula 70-mer oligonucleotides.

b TIGR ID, identifier in the TIGR M. truncatula Gene Index.

${ }^{\mathrm{C}} \mathrm{M}=\log _{2}$ expression ratio P665/Messire at 16, 24 and 48 hours after inoculation.

* $M \leq-0.8$ or $M \geq 0.8$ are significant at significance level of 0.05 using t-test and FDR correction.

Genes of the functional categories (FC): I (Cell wall), VI (Secondary metabolism and hormone metabolism), VIII (Gene expression and RNA metabolism), X (Signal transduction and post-translational regulation), XIIA (Defense and cell rescue) and XIIB (Abiotic stimuli and development) differentially expressed in P665 compared to Messire after inoculation with $M$. pinodes.

\section{Defense and cell rescue}

As expected, numerous sequences corresponding to genes involved in defense were more expressed in P665 comparing to Messire. Those included, among others, sequences encoding peroxidases, a disease resistance response protein 39 precursor, nine-cis-epoxycarotenoid dioxygenase and glutathione S-transferases. However other proteins with possible roles in defense were less expressed in P665. Those included GA protein, PR-10, ascorbate peroxidase and a putative NBS-LRR type disease resistance protein.

\section{Abiotic stimuli and development}

Different proteins related to the response to 'Abiotic stimuli and development' category were also found to be differentially regulated in P665 comparing to Messire. Up-regulated proteins included ripening-related proteins, cold- and wound-inducible proteins. An auxininduced protein and a putative $16.9 \mathrm{kDa}$ heat shock protein were down-regulated.

\section{qRT-PCR}

In general, $\mathrm{M}$ values obtained by qRT-PCR showed the same trend as those obtained by microarray (Table 2). However, the sequence MT014356, showing similarities with 12-oxophytodienoate reductase (OPR2), was up regulated according to the microarray experiment but down regulated according to $\mathrm{qRT}$-PCR. In addition, the gene 6a-hydroxymaackiain methyltransferase showed also almost no regulation in the qRT-PCR experiment while was down regulated in the microarray experiment.

Quantitative RT-PCR techniques was used not only to validate the microarray data, but also to investigate the expression level of 10 selected genes in non-inoculated P665 and Messire plants. That allowed a calculation of the fold changes of different genotype and treatment combinations and hence provided interesting extrainformation about the regulation of these genes.

The gene PsOXII, encoding a peroxidase, was more expressed in P665 than in Messire after inoculation with M. pinodes (Table 3). That was mainly due to a constitutively higher expression level of this gene in P665, as PsOXII was up-regulated after inoculation in both genotypes but in a similar amount. That was also the case of the disease resistance response protein 39 (DRR230-b), where the higher expression level of the gene in P665 after inoculation was also due to a constitutively higher expression in P665.

12-oxophytodienoic acid 10,10-reductase was downregulated in P665 as compared to Messire after inoculation according to qRT-PCR. That was caused by a high induction of this gene after inoculation in Messire, while the expression of this sequence was almost not induced 
Table 2 qRT-PCR validation of 10 differentially expressed genes according to microarray experiment

\begin{tabular}{|c|c|c|c|c|c|}
\hline Oligo ID ${ }^{a}$ & TIGR ID & Annotation & $\mathrm{Hai}^{\mathrm{C}}$ & $M^{d}$ microarray & M qRT-PCR \\
\hline MT014704 & TC80412 & Peroxidase & 48 & 1.56 & 2.99 \\
\hline MT006316 & TC82368 & Disease resistance response protein 39 precursor & 16 & 1.29 & 0.91 \\
\hline MT014356 & TC85808 & 12-oxophytodienoate reductase (OPR2) & 16 & 1.27 & -1.62 \\
\hline MT014726 & TC79559 & glutathione S-transferase & 16 & 1.96 & 2.25 \\
\hline MT007682 & TC77455 & nine-cis-epoxycarotenoid dioxygenase 1 & 16 & 1.12 & 0.21 \\
\hline MT000707 & TC86358 & 6a-hydroxymaackiain methyltransferase & 16 & -2.13 & -0.03 \\
\hline MT000671 & TC86307 & ferredoxin-NADP+ reductase & 48 & -1.2 & -2.3 \\
\hline MT014197 & TC85300 & chlorophyll a/b-binding protein & 48 & -1.34 & -1.33 \\
\hline MT007613 & TC86304 & GA protein & 48 & -2.28 & -2.65 \\
\hline МT014137 & BF633423 & ribulose 1 5-bisphosphate carboxylase small subunit & 48 & -0.92 & 0.32 \\
\hline
\end{tabular}

${ }^{a}$ Oligo ID, identifier of $M$. truncatula 70-mer oligonucleotides.

b TIGR ID, identifier in the TIGR M. truncatula Gene Index.

${ }^{c} \mathrm{Hai}=$ hours after inoculation with $M$. pinodes.

${ }^{\mathrm{d}} \mathrm{M}=\log _{2}$ expression ratio $\mathrm{P} 665 /$ Messire.

e Primers used to amplify the genes are shown in Table 4.

after inoculation with M. pinodes in P665. In addition, this sequence was constitutively less expressed in P665 than in Messire.

A glutathione S-transferase like gene was constitutively around 4 times more expressed in P665 than in Messire and was slightly induced after inoculation in both genotypes. As a result, P665 inoculated plants showed a higher level of expression of this gene than those of Messire.

The nced 4 gene, encoding a nine-cis-epoxycarotenoid dioxygenase 4 , had a similar regulation pattern in both genotypes. Thus, both genotypes possessed a constitutively similar level of expression of the gene and in both genotypes the gene was repressed after inoculation with $M$. pinodes. Consequently, the level of expression of this

Table $3 \log _{2}$ of normalized expression ratios according to qRT-PCR

\begin{tabular}{lcccc}
\hline Gene & PI/MI & PC/MC & PI/PC & MI/MC \\
\hline Peroxidase (PsOXII) & 2.99 & 3.8 & 0.83 & 0.84 \\
$\begin{array}{l}\text { Disease resistance response protein } \\
\text { 39 (DRR230-b) }\end{array}$ & 0.91 & 1.30 & 1.20 & 1.63 \\
$\begin{array}{l}\text { 12-oxophytodienoic acid 10,10- } \\
\text { reductase (OPR1) }\end{array}$ & -1.62 & -1.22 & 0.37 & 3.5 \\
$\begin{array}{l}\text { Glutathione S-transferase } \\
\text { Nine-cis-epoxycarotenoid }\end{array}$ & 2.25 & 2.11 & 0.30 & 0.55 \\
dioxygenase 4 (nced4) & 0.20 & 0.04 & -0.60 & -0.89 \\
$\begin{array}{l}\text { 6a-hydroxymaackiain } \\
\text { methyltransferase (hmm6) }\end{array}$ & -0.03 & 0.93 & 1.06 & 2.41 \\
$\begin{array}{l}\text { Ferrodoxin NADP oxidoreductase } \\
\text { Chlorophyll a/b-binding protein }\end{array}$ & -2.3 & -0.5 & -0.87 & 1.13 \\
GA protein & -2.63 & -0.13 & -1.4 & 0.02 \\
Ribulose 1 5-bisphosphate & 0.32 & 0.6 & -1.6 & 0.31 \\
carboxylase small subunit & & & & 0.19 \\
\hline
\end{tabular}

$\log _{2}$ of normalized expression ratios of 10 genes in control (C) and inoculated (I) plants of lines P665 (P) and Messire (M) according to qRT-PCR. gene in P665 was similar to that of Messire after inoculation.

hmm6 gene, encoding a 6a-hydroxymaackiain methyltransferase, was constitutively around 2 times more expressed in P665 than in Messire. After inoculation with $M$. pinodes this gene was over expressed in both genotypes but more strongly in Messire. As a result this gene showed a similar level of expression in both genotypes after inoculation.

Ferrodoxin NADP oxidoreductase was less expressed in P665 than in Messire after inoculation. This gene was repressed in $\mathrm{P} 665$ after inoculation with $M$. pinodes but induced in Messire. In addition, in P665 control plants this gene was less expressed than in Messire ones.

Messire plants inoculated with M. pinodes showed a higher level of expression of chlorophyll a/b-binding protein than P665 plants. Constitutively, both genotypes had a similar level of expression of the gene but this protein was repressed after inoculation in P665 while it was not differentially regulated in Messire.

Messire plants inoculated with $M$. pinodes showed also a higher expression level of a GA protein encoding gene than P665. In this case, the gene was also repressed after inoculation in P665 and only slightly induced in Messire. In addition, the level of expression of the gene in control plants was lower in P665 than in Messire.

The gene encoding ribulose 15 -bisphosphate carboxylase small subunit showed almost no regulation after inoculation with $M$. pinodes in both genotypes and was not differentially expressed in control plants of both genotypes.

\section{Discussion}

Resistance to M. pinodes in pea is a complex trait. Only incomplete resistance to this disease has been identified 
and genetic analyses have shown that numerous genomic regions are involved in resistance [13-17]. In addition, the necrotrophic nature of $M$. pinodes complicates the performance of histological studies to elucidate the mechanisms of resistance acting to this pathogen. As a consequence, very little is known about the genes and mechanisms of resistance conferring resistance to this important disease. The present study offers a global view of genes and metabolic pathways expressed in a resistant interaction with $M$. pinodes and hence provides an excellent tool to increase our knowledge about pea$M$. pinodes interaction and to identify candidate genes useful for marker assisted selection.

Previous studies have given some insight into defence responses induced after infection with $M$. pinodes or treatment with a $M$. pinodes elicitor. These studies were performed in susceptible pea lines and showed that the $M$. pinodes elicitor induced the production of the phytoalexin pisatin, the enzymes chalcone sintase and phenylalanine ammonia-lyase, PR proteins as chitinase and endo-b-1,3-glucanase and the generation of superoxide anion. ATPase activity and polyphosphoinositide metabolisms were also activated. On the other hand, $M$. pinodes produces two suppressors that inhibit these defence responses [23-28]. The present study is the first report on genes differentially expressed after infection with $M$. pinodes in a resistant line. We compared gene expression profiling in this resistant line with that of a susceptible line using the microarray technology. This approach can contribute to the identification of the specific genes and mechanisms conferring resistance to $M$. pinodes in pea.

The microarray technology allows the simultaneous assessment of the expression of thousands of genes, being an excellent tool to characterize, at the transcription level, several processes such as defence response to pathogens. As sequence information in pea is limited, we used a microarray containing 70-mer oligos representing all tentative consensus sequences (TCs) of the TIGR M. truncatula Gene Index 5. We obtained a successful cross-hybridization between pea targets and M. truncatula probes. That result was expected due to the high level of homology and syntheny between these two species [29-31]. A high level of data quality and reproducibility was achieved through the use of tree independent biological replicates and two technical replicates, the use of negative controls and a strict statistical analysis to select the genes differentially expressed.

Comparison between microarray and qRT-PCR results showed common expression kinetics for many of the genes indicating that this microarray experiment is a useful tool to select candidates genes potentially involved in resistance to $M$. pinodes in pea. However, our results also indicate that the involvement of these candidate genes in resistance to $M$. pinodes must be verified by qRT-PCR using Pisum sequences. Differences observed between microarray and qRT-PCR may be due to the presence of different gene isoforms or to the cross-hybridization between $M$. truncatula probes and different Pisum genes having similar sequences. For example, microarray experiment showed that a $M$. truncatula sequence showing similarities to the gene 12-oxophytodienoate reductase (OPR2) was more expressed in P665 than in Mesire. OPR genes are highly similar to each other. Therefore, to investigate by qRTPCR which OPR gene was up regulated we used a primer pair based on the sequence of the Pisum gene OPR1. But these primers were also able to amplify the genes OPR2, OPR3, OPR4 and OPR6. So, is possible that we have amplified by qRT-PCR sequences corresponding to different genes belonging to this family showing different expression levels. Therefore, further experiments using primers specific for each OPR gene are needed to discern which of them is more expressed in P665 than in Messire after inoculation with $M$. pinodes. In the case of the gene ' $h m m 6,6 a$-hydroxymaackiain methyltransferase,'in the microarray there were a $M$. truncatula sequence (MT000707) showing similarities to this gene that was strongly down regulated in P665 comparing to Messire. However, when primers were designed according to the pea sequence of this gene (NCBI accession U69554.1) and the gene was amplified by qRT-PCR, results obtained showed that this gene was not differentially regulated in P665 comparing to Messire. Therefore it is possible that other pea genes, different from '6a-hydroxymaackiain methyltransferase' but having a sequence similar to the probe MT000707, or other unknown isoforms of the gene are also able to hybridise to this probe interfering in the results. In addition, the probe MT000707 has homology with the fragment of the gene located from 1041 to $1094 \mathrm{pb}$ (accession U69554.1), while for qRT-PCR we used a pair of primers that amplified the region of the gene located between 730 and $809 \mathrm{pb}$. Therefore, as we have checked different fragments by microarray and qRT-PCR, another possibility is that P665 differs from Messire in the fragment of the gene corresponding to the probe MT000707. That hypothesis could be further clarified by amplifying by qRT-PCR the fragment of the gene located between 1041 and $1094 \mathrm{pb}$.

Plants express a wide range of defence responses that can contribute to resistance to pathogens. These include preformed structural and chemical components, activation of the phytoalexin biosynthetic pathway, production of PR proteins, cell wall reinforcement mediated by hydrogen peroxide and detoxification of fungal toxins. Our results suggest that several of these mechanisms may contribute to resistance to $M$. pinodes in pea accession P665. 
In interactions with susceptible genotypes, $M$. pinodes spores germinate producing a germ tube and penetrate the pea cuticle directly through the wall of the epidermal cells. Beneath the cuticle, hyphae grow within the outer wall of the epidermis being predominantly aligned with the longitudinal axis of the epidermal cells. Subsequently hyphae grow further within the periplasmic space between plasmalemma and wall, displacing the cell contents, but not causing collapse of the protoplast. This probably biotrophic phase is followed by a necrotrophic one in which $M$. pinodes causes necrotic lesions in the pea mesophyll. These necrotic lesions rapidly spread in susceptible genotypes and hyphae can grow beyond the necrotic zone [32,33]. Previous histological studies performed by the authors [34] indicated that in P665 a proportion of $M$. pinodes infection units were stopped at the epidermal cells not being able to reach the mesophyl. This lower success in establishing colonies was associated with a rapid death of the epidermal cell that was being infected, resembling a hypersensitive response. In addition, those infection units that succeeded penetrating the epidermis and reached the mesophyll in P665 resulted in lesions significantly smaller than those formed in the susceptible line Messire. These results suggest that a battery of resistance mechanisms are acting in P665, starting from a barrier stopping the infection of $M$. pinodes at the epidermis and further barriers acting after the pathogen has penetrated epidermis and reached the mesophyll restricting the growth of $M$. pinodes in the mesophyll. Several genes involved in cell wall fortification were found to be more expressed in P665 than in Messire in the microarray experiment. The involvement of wall reinforcement in the resistance to $M$. pinodes in pea has been suggested by Clulow and Lewis [33] and Wroth [12]. This cell wall reinforcement could contribute to the development of physical barriers hampering the expansion of M. pinodes within the P665 tissues or reducing the diffusion of pathogenic toxins. In our microarray experiment 'repetitive proline-rich cell wall proteins', that are structural proteins of the primary cell wall involved in cell wall strengthening, and a 'caffeic acid O-methyltransferase' involved in the lignin synthesis were up regulated in P665 comparing to Messire. In addition, enzymes involved in the production of $\mathrm{H}_{2} \mathrm{O}_{2}$, such as 'peroxidases' and 'amine oxidase' were found also to be up-regulated. $\mathrm{H}_{2} \mathrm{O}_{2}$ is thought to be required for lignification of the cell wall and for the oxidative crosslinking of hydroxyproline-rich glycoproteins in the cell wall $[35,36]$. The accumulation of reactive oxygen species (ROS) is also associated with the occurrence of hypersensitive response [37] that may play a role in the resistance of line P665 to M. pinodes. ROS can also be toxic and inhibit fungal growth [38] and act as signaling agents in plant defense [39].
In addition to ROS, other compounds have antimicrobial properties and can contribute to the inhibition of pathogens development. The recognition of a pathogen by the plant activates several defensive responses including the activation of the phenylpropanoid metabolism and the production of phytoalexins [40]. Phenylpropanoids are a group of plant secondary metabolites derived from phenylalanine that have a wide variety of functions, including defense against microbial attacks or other sources of injury. Phytoalexins are plant antibiotics that are synthesized after the plant tissue is exposed to microbial infection. The production of these antifungal compounds has a relevant role in plant defence. Our results indicate that many enzymes involved in their synthesis were higher expressed in P665 than in Messire after inoculation with $M$. pinodes. Those included 'UDPglycose flavonoid glycosiltransferase', 'coumarate $\mathrm{CoA}$ ligase like protein', 'phenylalanine ammonia-lyase', 'flavanone 3 beta-hydroxylase' and 'hyoscyamine 6 betahydroxylase'. However, other enzymes of these pathways as 'flavonol synthase', 'tropinone reductase" and "amygdalin hydrolase isoform AH I precursor" were down regulated.

In addition, qRT-PCR data showed that the enzyme '6a-hydroxymaackiain methyltransferase', which catalyses the last step of the synthesis of pisatin, the main pea phytoalexin, is constitutively at a higher concentration in P665 than in the susceptible cultivar Messire. This enzyme was activated after inoculation with $M$. pinodes in both genotypes and both genotypes showed similar amount of this enzyme 16hai. The constitutively higher expression of this enzyme in P665, suggests that in P665 pisatin can start acting earlier against the pathogen and can reach the same final level as Messire with a lower effort by the plant.

Pathogenesis- related $(\mathrm{PR})$ proteins are also induced during infection by pathogens and several of them possess antimicrobial properties [41]. The PR14 are 'lipid transfer protein' and a sequence encoding such a protein was up regulated in P665. Another up-regulated PR protein encoded a precursor of the defensin 'disease resistance response 39 (DRR230-b)'. This gene was induced after infection with $M$. pinodes and showed a constitutively higher expression in P665 comparing to Messire. DRR230-b defensin was first identified by Chian and Hadwiger [42] from pea pods in response to infection by the fungal pathogen Fusarium solani. The gene encoding 'disease resistance response 39 precursor' was also present in a cDNA library obtained from a resistant Lathyrus sativus accession inoculated with $M$. pinodes [43]. More recently, this defensin was found to co-localize with the QTL mpIII-4 involved in field resistance to $M$. pinodes in pea [18]. In addition, the related defensins DRR230-a and DRR230-c were also found to be induced 
after infection with several pathogens including $A$. pinodes (the teleomorph of $M$. pinodes) [44]. Our results reinforce these recent studies suggesting the important role of this protein in resistance to diseases in pea, and specially in resistance to $M$. pinodes.

Necrotrophic fungi, as $M$. pinodes, kill host tissues during infection, usually through the secretion of toxic substances. Therefore, the ability of a plant to detoxify these fungal toxins may contribute to resistance to necrotic pathogens. Thus, chickpea cultivars with higher sensitivity to the phytoxins produced by Ascochyta rabiei are more susceptible to this pathogen [45]. Our results show that $\mathrm{P} 665$ may posses a higher ability to detoxify $M$. pinodes toxins as two genes involved in detoxification processes, the 'glutatione S-transferase' and 'ABC transporter', were found to be more expressed in P665 than on Messire. Glutatione S-transferases are involved in several metabolic processes and in the detoxification of a wide variety of compounds including microbial toxins [46]. ATP-binding cassette transporters (ABC-transporter) are transmembrane proteins that function in the transport of a wide variety of substrates across extra- and intracellular membranes including toxins, drugs, glutatione conjugates, peptides and secondary metabolites $[47,48]$.

In addition to the genes reported above, other genes involved in defence were also up-regulated in P665. These included a "syringolide-induced protein" that have been found to be induced after treatment with the syringolide elicitors produced by the bacteria Pseudomonas syringae [49]. Other up-regulated genes with a possible involvement in defence were genes encoding lectins, as several plant lectins have been shown to induce the production of pisatin [50].

Perception of both general and specific pathogen associated molecules triggers defence responses via signal transduction cascades and transcriptional activation of numerous genes [51]. The expression of transcription factors and proteins kinases, as well as elevation of cytosolic calcium, is integral to the signalling of these defences [52]. We identified several genes involved in signal recognition and transduction pathways, such as kinases, $\mathrm{CCCH}$-type zinc finger protein and transcription factors, that were differently expressed in P665 comparing to Messire after inoculation with $M$. pinodes. Among the differentially regulated transcriptional factors there were some associated with Jasmonic Acid (JA) and Ethylene (ET): "ethylene responsive element binding factor-like", "transcription factor JERF1" and "pathogenesis related transcriptional factor ERF". This suggests that the response to $M$. pinodes in pea is regulated via JA and ET pathways. This is in agreement with the predominant necrotrophic nature of $M$. pinodes, as gene-for gene resistance and SA signalling are generally effective against biotrophic pathogens whereas JA/ET signalling is generally effective against necrotrophs [53].

In addition to genes involved in defence against pathogens also genes involved in response to abiotic stresses and development such as 'ripening-related protein-like', 'CIC protein cold-inducible' and 'wound-induced protein T9A4.6' were more expressed in P665 than in Messire showing that response to abiotic and biotic stresses and proteins involved in development are interlinked, as many other studies suggest. For example a "ripening related protein" was found also to be expressed in a pea line resistant to Erysiphe pisi [54] and in the model legume legume Medicago truncatula in response to the parasitic plant Orobanche crenata [55].

Our results suggest that resistance to $M$. pinodes in P665 is in part due to a constitutively higher expression of genes involved in defense such as peroxidases, DRR230-b, GST and 6a-hydroxymaackiain methyltransferase. The first step in the response to a pathogen is the recognition of the pathogen by the plant. This recognition leads to the induction of the defence responses. In gene-for-gene resistance, early recognition of specific pathogen strains, a key step in a successfully defense, depends on complementary pairs of dominant genes, one in the host and one in the pathogen. Genefor-gene resistance is common in interactions with many biotrophic pathogens [56]. In contrast, resistance mediated by a single host resistance gene is uncommon in the case of necrotrophic fungal pathogens. In the case of necrotrophic pathogens plants usually recognize non-specific elicitors that activate a battery of basal defense responses that act against a wide range of pathogens. In this case, as is the case of resistance to the necrotrophic fungi $M$. pinodes, the recognition of a pathogen is not so fast and a preformed higher expression of genes with antimicrobial properties can be an advantage to get a fast and effective defence response.

\section{Conclusions}

In this study, we have obtained a global view of genes expressed during resistance to $M$. pinodes. This gave us information about the possible mechanisms and pathways involved in the resistance to this important disease such as cell wall reinforcement, production of phytoalexins, phenylpropanoids and PR proteins and detoxification of fungal toxins. This study is also an useful tool to identify candidates genes involved in the control of resistance to $M$. pinodes in pea useful for marker assisted selection. Further studies will include the mapping of the most relevant genes identified in this study in a RIL population derived from the cross P665 x Messire where QTLs associated with resistance to $M$. pinodes have been identified and functional analysis to discern the role of these genes in resistance. 


\section{Methods}

\section{Plant material and inoculation}

Two pea genotypes, P665 and Messire, the parental lines of a RIL population previously used to identify QTLs associated with resistance to $M$. pinodes [13] were used in the experiment. Messire is a commercial Pisum sativum ssp. sativum cultivar highly susceptible to M. pinodes. P665 is a P. sativum ssp. syriacum accession displaying incomplete resistance to $M$. pinodes [11]. Previous histological studies revealed that resistance to $M$. pinodes in accession P665 was characterized by a lower succeed in colony establishment, associated with the rapid death of the epidermal cell being attacked by $M$. pinodes and by a smaller colony size [34].

For inoculation plants were grown until the fifth leave stage in a growth chamber $\left(20 \pm 2^{\circ} \mathrm{C}\right.$ with a $12 \mathrm{~h}$ dark/ $12 \mathrm{~h}$ light photoperiod, at $250 \mu \mathrm{mol} \mathrm{m}^{-2} \mathrm{sec}^{-1}$ ). Plants were inoculated with the monoconidial $M$. pinodes isolate C0-99, obtained from infected pea material collected in commercial fields at Córdoba, Spain. The isolate was multiplied in Petri dishes containing V8 juice medium located in a growth chamber at $21 \pm 2^{\circ} \mathrm{C}$ with a $12 \mathrm{~h}$ dark $/ 12 \mathrm{~h}$ light photoperiod, at $106 \mathrm{lmol} / \mathrm{m}^{2} \mathrm{~s}$. A spore suspension was prepared by flooding the surface of 12 days old cultures with sterile water, scraping the colony with a needle and filtering the suspension through two layers of sterile cheesecloth. The concentration of spores in the solution obtained was further determined with a haemocytometer and adjusted to 350.000 spores per ml. Finally, Tween-20 (120 $\mu \mathrm{l}$ per $100 \mathrm{ml}$ of suspension) was added as a wetting agent and the spore suspension was applied with a sprayer at a rate of $1 \mathrm{ml}$ per plant. After inoculation high humidity was ensured during the first $24 \mathrm{~h}$ by ultrasonic humidifiers operating for 15 minutes every two hours. After that period the humidifiers were turned off.

The experiment was performed in three independent replicates, each having 3 to 5 plants per genotype (Messire/P665), treatment (inoculated/control) and time of harvesting (16, 24 and 48 hours after inoculation). In each replicate, plants grown under the same conditions but not inoculated were used as control.

\section{Sample collection and RNA extraction}

At 16, 24 and 48 hours after inoculation (hai) leaflets of control and inoculated plants were harvested, immediately frozen in liquid nitrogen and stored at $-80^{\circ} \mathrm{C}$. RNA was isolated using Trizol reagent (Invitrogen, Karlsruhe, Germany) according to manufacture's protocols. Integrity of total RNA was checked on agarose gels and its quantity, as well as purity, was determined using NanoDrop ND1000 (NanoDrop Technologies, Inc., Wilmington, USA). RNA from infected plants was further purified and concentrated to $0.8 \mu \mathrm{g} / \mu \mathrm{l}$ using Microcon-30 YM columns (Millipore, Schwalbach, Germany).

\section{Microarray experiment}

Microarray experiment was performed at the Institute for Genome Research of Bielefeld University, Germany. For each time of harvesting and replicate, Cy-labelled cDNA samples from resistant and susceptible inoculated plants labelled with different Cy dies were co-hybridized to Mt16kOLI1Plus microarray as described by Küster et al. [57]. The experiment included three biological and two technical replicates incorporating one dye swap. The resulting images were analysed using the ImaGene 5.5 software (Bio-Discovery, Los Angeles) as described by Hohnjec et al., [58]. Data files were imported into the EMMA1.1 array analysis software [59] and normalized using Lowess normalization. To identify the genes differentially expressed in the inoculated resistant genotype compared to the susceptible one a t-test followed by FDR correction was performed. Genes were considered differentially regulated when $\mathrm{p} \leq 0.05$ and $\mathrm{M} \leq-0.8$ or $M \geq 0.8$, being $M=\log _{2}$ (red/green). The microarray data have been deposited into the public data base ArrayExpress (E-TABM-1084).

\section{Data validation by quantitative real time Reverse Transcription PCR ( $q R T-P C R$ )}

The expression profiles of 10 genes differentially expressed according to the microarray experiment were validated in inoculated and control plants using two steps qRT-PCR. Total RNA was extracted from different samples obtained from the same three replicates used for microarray study using TRISure (Bioline, London, UK). After checking its quality, any possible residual genomic DNA was removed using RQ1 RNase-Free Dnase (Promega, Madison, USA). RNA was further purified using RNeasy Plant Mini Kit (Quiagen, Hilden, Germany). The absence of genomic DNA was checked by PCR using specific primers that amplify and intronexon-intron sequence of the $P$. sativum gene glyceraldehyde-3-phosphate dehydrogenase (GAPDH) (Fw: 5'-3': GTGGTCTCCACTGACTTTATTGGT/Rv 5'-3': TTC CTGCCTTGGCATCAAA, Die et al., 2010). Total RNA $(5 \mu \mathrm{g})$ was reverse-transcribed using SuperScript III First-Strand Synthesis System for RT-PCR (Invitrogen, Karlsruhe, Germany).

In order to ensure equal starting cDNA amounts, realtime PCR amplification of $\alpha$-Tubuline (TUB) was run for all the different templates and, depending on the CT (threshold cycle) number, cDNA samples were diluted to obtain similar CT values. In addition, to check the quality of the reverse transcription, specific primers were used to amplify in each template two fragments of the gene GAPDH located 915 bp apart at the 5'or 3'end of the transcript (GAPDH1 Fw 5'-3': ctccactgactttattggtgaca/Rv 5'-3': caaacttgtcatttaaggcaattc; GAPDH2 Fw 5'-3': tcaagatcggaatcaacggatt/Rv 5'-3': cgagttcaacatcat ctctcttcaa). 
Table 4 Primers used to amplify 10 candidate genes by qRT-PCR

\begin{tabular}{|c|c|c|c|}
\hline Gene & Forward primer $\left(5^{\prime}-3^{\prime}\right)$ & Reverse primer $\left(5^{\prime}-3^{\prime}\right)$ & Reference accession \\
\hline Peroxidase (PsOXII) & cttggaggacccacatggat & tttggcttgctgttcttgca & GenBank: AB193816.1 \\
\hline Disease resistance response protein 39 (DRR230-b) & gggagtatgcttcacgaatgc & ttttgagtgcagaaacatttcca & GenBank: LO1579.1 \\
\hline 12-oxophytodienoic acid 10,10-reductase (OPR1) & aagtgaatgacagaaccgatga & atggaaaccgacagcgatt & GenBank: AY954368.1 \\
\hline Glutathione S-transferase & gttcgtcctcctccgctaact & gttcgtcctcctccgctaact & GenBank: AB087837 \\
\hline Nine-cis-epoxycarotenoid dioxygenase 4 (nced4) & ctctcttcccgaacgtcttctc & cgcacgtggatccataaccgcc & GenBank: U69554.1 \\
\hline 6a-hydroxymaackiain methyltransferase (hmm6) & tttgaactttgttggtggagatatg & aatcatgcagaacccacttgagt & GenBank: U69554.1 \\
\hline Ferrodoxin NADP oxidoreductase & acaagcaagtgtgccgaaagt & ggaggttcagaaaggattttcca & GenBank: X99419.1 \\
\hline Chlorophyll a/b-binding protein & gttttcgcatcaacggactt & attgcccaccagggtaaag & GenBank: EF488077.1 \\
\hline GA protein & tgcagacagctttaacctttgc & tgcgagacactctttggtgttg & GenBank: X65154.1 \\
\hline Ribulose 1 5-bisphosphate carboxylase small subunit & caagtcttgaaggagcttgatgaa & gttgtcgaaaccgatgatacga & GenBank: J01257.1 \\
\hline
\end{tabular}

Polymerase chain reactions were performed in a 96-well plate with a 7500 Real Time PCR System (Applied Biosystems, Foster City, CA, USA), using SYBR Green to monitor dsDNA synthesis. Reactions contained $0.5 \mu \mathrm{l}$ of Fast Start Universal SYBR Green Master (ROX), $1 \mu \mathrm{l}$ of cDNA, and $0.3 \mu \mathrm{M}$ of each gene-specific primer in a final volume of $10 \mu \mathrm{l}$. The following standard thermal profile was used for all PCR reactions: polymerase activation $\left(95^{\circ} \mathrm{C}\right.$ for $\left.10 \mathrm{~min}\right)$, amplification and quantification cycles repeated 40 times $\left(95^{\circ} \mathrm{C}\right.$ for 15 seconds, $60^{\circ} \mathrm{C}$ for $\left.1 \mathrm{~min}\right)$ and dissociation curve $\left(95^{\circ} \mathrm{C}\right.$ 15 seconds, $60^{\circ} \mathrm{C} 1 \mathrm{~min}, 95^{\circ} \mathrm{C} 30$ seconds).

$P$. sativum sequences with similarities to $5 \mathrm{M}$. truncatula microarray probes up-regulated in P665 compared to Messire and 5 down regulated were retrieved from NCBI data Base and used to design gene-specific primers using Probe Finder 2.45 (Universal Probe Library, Roche). The genes validated and primer sequences used are shown in Table 4 . In order to cover the range of variation of times points studied in the microarray experiment, the validation of the expression profiles of the genes by qRT-PCR was done with samples obtained at 16hai for five genes and with samples obtained at 48 hai for other 5 genes.

The genes TUB, histone H3 and GAPDH [60] were used as reference genes for normalization.

The PCR efficiency of each primer pair in each individual reaction was calculated using LingRegPCR 7.5 software and used to calculate an average efficiency (E) per primer pair. This average efficiency was used to calculate the expression in each reaction using the formula Expresion $=\mathrm{E}^{\mathrm{CT}}$. A normalization index was calculated for each plate as the geometric mean of the expression of the reference genes TUB, GAPDH and histone $\mathrm{H} 3$ and a relative expression was calculated for each reaction as the ratio of the gene expression of the gene of interest in each reaction against the normalization index.

\section{Additional material}

Additional file 1: Table S1. Genes differentially expressed in the resistant accession P655 comparing to the susceptible one cv Messire at 16,24 and 48 hours after inoculation (hai) with M. pinodes. Genes induced are listed according to the functional categories as defined by Journet et al. (2002) and are sorted within these classes according to the induction level at 16 hai. Oligo ID = identifier of $M$. truncatula 70 mer oligonucleotides. F.C $=$ functional categories as defined by Journet et al. (2002). $M=\log 2$ (expresion ratio). TIGR ID = identifier in the TIGR M. truncatula Gene Index. Annotation = annotations according to TIGR release http://compbio.dfci.harvard.edu/tgi/ Empty cells means that no significance was detected at $\mathrm{P}<0.05$ or $\mathrm{M}>-0.8$ or $\mathrm{M}<0.8$.

\section{Acknowledgements}

The authors thank the Spanish Ministry of Science and Innovation for providing a 'Juan de la Cierva' contract to the senior author and AGL200801239 and FP6-CT-2004-FOOD-1-506223 projects for financial support.

\section{Author details}

'Department of Genetics, University of Córdoba, Campus de Rabanales, E-

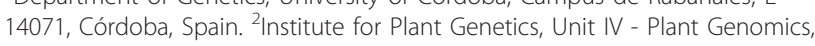
Leibniz Universität Hannover, Herrenhäuser Str. 2, D-30419 Hannover, Germany. ${ }^{3}$ Max-Planck Institute of Molecular Plant Physiology, Wissenschaftspark Golm, Am Muehlenberg 1, 14476,Potsdam, Germany. ${ }^{4}$ CSIC, Institute for Sustainable Agriculture, Apdo. 4084, E-14080,Córdoba, Spain.

\section{Authors' contributions}

SF carried out the inoculations with $M$. pinodes, extracted the RNA, performed the GRT-PCR assays and drafted the manuscript. HG performed the microarray hibridizations. FK was involved in the microarray experiment design and data analysis and in the critical revision of the manuscript. JIC carried out a critical revision of the manuscript. DR conceived the study, provided the funding to do the experiments and supervised the research. All authors read and approved the final manuscript.

Received: 20 August 2010 Accepted: 13 January 2011

Published: 13 January 2011

\section{References}

1. Köpje U, Nemecek T: Ecological services of faba bean. Field Crops Res 2010, 115:217-233.

2. FAOSTAT:[http://faostat.fao.org/site/567/default.aspx\#ancor].

3. Moussart A, Tivoli B, Lemarchand E, Deneufbourg F, Roi S, Sicard G: Role of seed infection by the Ascochyta blight pathogen of dried pea (Mycosphaerella pinodes) in seedling emergence, early disease 
development and transmission of the disease to aerial plant parts. Eur J Plant Pathol 1998, 104:93-102.

4. Lawyer SA: Diseases caused by Ascochyta spp. In Compendium of pea diseases. Edited by: Hargedon DJ. St Paul, Minnesota: APS Press; 1984:11-15.

5. Wallen VR: Field evaluation of the importance of the Ascochyta complex of peas. Can J Plant Sci 1965, 45:27-33.

6. Rubiales D, Pérez-de-Luque A, Cubero Jl, Sillero JC: Crenate broomrape (Orobanche crenata) infection in field pea cultivars. Cro Prot 2003, 22:865-872.

7. Xue AG, Warkentin TD, Kenaschuk EO: Effect of timings of inoculation with Mycosphaerella pinodes on yield and seed infection on field pea. Can J Plant Sci 1997, 77:685-689.

8. Clulow SA, Lewis BG, Matthews P: A pathotype classification for Mycosphaerella pinodes. Phytopathology 1991, 131:322-332.

9. Kraft JM: A search for resistance in peas to Mycosphaerella pinodes. Plant Dis 1998, 82:251-253.

10. Wroth JM: Host- pathogen relationship of the ascochyta bligt (Mycosphaerella pinodes (Berk \& Blox) Vesterg ) disease of field pea (Pisum sativum L ). PhD. thesis University of Western Australia, Perth; 1996.

11. Fondevilla S, Ávila CM, Cubero Jl, Rubiales D: Response to Mycosphaerella pinodes in a germplasm collection of Pisum spp. Plant Breeding 2005, 124:313-315.

12. Wroth JM: Possible role for wild genotypes of Pisum spp. to enhance ascochyta bligt resistance in pea. Aust J Exp Agr 1998, 38:469-479.

13. Fondevilla S, Satovic Z, Rubiales D, Moreno MT, Torres AM: Mapping of quantitative trait loci for resistance to Mycosphaerella pinodes in Pisum sativum subsp. syriacum. Mol Breeding 2008, 21:439-454.

14. Prioul S, Frankewitz A, Deniot G, Morin G, Baranger A: Mapping of quantitative trait loci for partial resistance to Mycosphaerella pinodes in pea (Pisum sativum L.) at the seedling and adult plant stages. Theor Appl Genet 2004, 108:1322-1334.

15. Tar'an B, Warkentin T, Somers DJ, Miranda D, Vandenberg A, Balde S, Woods S, Bing D, Xue A, DeKoeyer D, Penner G: Quantitative trait loci for lodging resistance, plant height and partial resistance to mycosphaerella blight in field pea (Pisum sativum L.). Theor Appl Genet 2003, 107:1482-1491.

16. Timmerman-Vaughan GM, Frew TJ, Russell AC, Khan T, Butler R, Gilpin M, Murray S, Falloon K: QTL mapping of partial resistance to field epidemics of ascochyta blight of pea. Crop Sci 2002, 42:2100-2111.

17. Timmerman-Vaughan GM, Frew TJ, Butler R, Murray S, Gilpin M, Falloon K, Johnston P, Lakeman MB, Russell AC, Khan T: Validation of quantitative trait loci for Ascochyta blight resistance in pea (Pisum sativum L.), using populations from two crosses. Theor Appl Genet 2004, 109:1620-1631.

18. Prioul-Gervais $S$, Deniot $G$, Receveur EM, Frankewitz A, Fourmann M, Rameau C, Pilet-Nayel ML, Baranger A: Candidate genes for quantitative resistance to Mycosphaerella pinodes in pea (Pisum sativum L.). Theor Appl Genet 2007, 114:971-984.

19. Dita MA, Die JV, Román B, Krajinski F, Küster H, Moreno MT, Cubero Jl, Rubiales D: Gene expression profiling of Medicago truncatula roots in response to the parasitic plant Orobanche crenata. Weed Res 2009, 49(Suppl. 1):66-80.

20. Bar-Or C, Kapulnik Y, Koltai H: A broad characterization of the transcriptional profile of the compatible tomato response to the plant parasitic root net nematode Meloidogyne javanica. Eur J Plant Pathol 2005, 111:181-192

21. Küster H, Becker A, Firnhaber C, Hohnjec N, Manthey K, Perlick AM, Bekel T, Dondrup M, Henckel K, Goesmann A, Meyer F, Wipf D, Requena N, Hildebrandt I, Hampp R, Nehls U, Krajinski F, Franken P, Pühler A: Development of bioinformatic tools to support EST-sequencing, in silicoand microarray-based transcriptome profiling in mycorrhizal symbioses. Phytochemistry 2007, 68:19-32.

22. Journet EP, van Tuinen D, Gouzy J, Crespeau H, Carreau V, Farmer M, Niebel A, Schiex T, Jaillon O, Chatagnier O, Godiard L, Micheli F, Kahn D, Gianinazzi-Pearson V, Gamas P: Exploring root symbiotic programs in the model legume Medicago truncatula using EST analysis. Nucleic Acids Res 2002, 30:5579-5592.

23. Kiba A, Miyake C, Toyoda K, Ichinose Y, Yamada T, Shiraishi T: Superoxide generation in extracts from isolated plant cell walls is regulated by fungal signal molecules. Phytopathol 1997, 87:846-852.

24. Shiraishi T, Oku H, Tsuji Y, Ouchi S: Inhibitory effect of pisatin on infection process of Mycosphaerella pinodes on pea. Ann Phytopathol Soc Jpn 1978, 44:641-645.
25. Shiraishi T, Saitoh K, Mo Kim H, Kato T, Tahara M, Oku H, Yamada T, Ichinose Y: Two suppressors, supprescins A and B, secreted by a pea pathogen, Mycosphaerella pinodes. Plant Cell Physiol 1992, 33:663-667.

26. Toyoda K, Koyama M, Mizukoshi R, Ichinose Y, Yamada T, Shiraishi T: Phosphorylation of phosphatidylinositols and production of lysophospholipid in pea plasma membrane are coordinately regulated by elicitor and suppressor from Mycosphaerella pinodes. Sci Rep Fac Agr Okayama Univ 1998, 87:109-116.

27. Yamada T, Shiraishi T, Ichinose Y, Kato H, Seki H, Murakami Y: Regulation of genes for phenylpropanoid synthesis in pea elicitor and suppressor. In Molecular aspects of phatogenicity and resistance: requirement for signal transduction. Edited by: Mills D, Kunoh H, Keen NT, Mayama S. St Paul: American Phytopathological Society; 1996:151-162.

28. Yoshioka H, Shiraishi T, Nasu K, Yamada T, Ichinose Y, Oku H: Suppression of activation of chitinase and B-1,3-glucanase in pea epicotyls by orthovanadate and suppressor from Mycosphaerella pinodes. Ann Phytopathol Soc Jpn 1992, 58:405-410.

29. Choi HK, Mun JH, Kim DJ, Zhu H, Baek JM, Mudge J, Roe B, Ellis N, Doyle J, Kiss GB, Young ND, Cook DR: Estimating genome conservation between crop and model legume species. Proc Natl Acad Sci USA 2004, 101:15289-15294.

30. Gualtieri G, Kulikova O, Limpens E, Kim DJ, Cook DR, Bisseling T, Geurts R: Microsynteny between pea and Medicago truncatula in the SYM2 region. Plant Mol Biol 2002, 50:225-235

31. Kalo P, Seres A, Taylor SA, Jakab J, Kevei Z, Kereszt A, Endre G, Ellis TH, Kiss GB: Comparative mapping between Medicago sativa and Pisum sativum. Mol Genet Genomics 2004, 272:235-246.

32. Clulow $S A$, Lewis $B G$, Matthews P: Infection of pea epicotyls by Mycosphaerella pinodes. Mycol Res 1991, 95(7):817-820.

33. Clulow SA, Lewis BG, Matthews P: Expression of resistance to Mycosphaerella pinodes in Pisum sativum. Plant Pathol 1992, 41:362-369.

34. Fondevilla S: Identification and characterization of sources of resistance to Mycosphaerella pinodes in Pisum spp. MSC thesis University of Córdoba, Genetic Department; 2000.

35. Brady JD, Fry SC: Formation of di-isodityrosine and loss of isodityrosine in the cell walls of tomato cell-suspension cultures treated with fungal elicitors or $\mathrm{H}_{2} \mathrm{O}_{2}$. Plant Physiol 1997, 115:87-92.

36. Brisson $L F$, Tenhaken $R$, Lamb C: Function of oxidative cross-linking of cell wall structural proteins in plant disease resistance. The Plant Cell 1994 6:1703-1712.

37. Torres MA, Jones JDG, Dangl JL: Pathogen-induced, NADPH oxidasederived reactive oxygen intermediates suppress spread of cell death in Arabidopsis thaliana. Nat Genet 2005, 37:1130-1134.

38. Lu H, Higgins VJ: The effect of hydrogen peroxide on the viability of tomato cells and of the fungal pathogen Cladosporium fulvum. Physiol Mol Plant Pathol 1999, 54:131-143.

39. Lamb C, Dixon RA: The oxidative burst in plant disease resistance. Annu Rev Plant Physiol Plant Mol Biol 1997, 48:251-275.

40. Dixon R, Achnine L, Kota P, Lui C, Reddy M, Wang L: The phenylpropanoid pathway and plant defense- a genomics perspective. Mol Plant Pathol 2002, 3:371-390.

41. van Loon $\mathrm{L}$, van Strien EA: The families of pathogenesis related proteins, their activities and comparative analysis of PR-1 type proteins. Physiol Mol Plant Pathol 1999, 55:85-97.

42. Chiang CC, Hadwiger LA: The Fusarium solani -induced expression of a pea gene family encoding high cysteine content proteins. Mol Plant Microbe Interact 1991, 4:324-331.

43. Skiba B, Ford R, Pang ECK: Construction of a CDNA library of Lathyrus sativus inoculated with Mycosphaerella pinodes and the expression of potential defence-related expressed sequence tags (ESTs). Physiol Mol Plant Pathol 2005, 66:55-67.

44. Lai FM, DeLong C, Mei K, Wignes T, Fobert PR: Analysis of the DRR230 family of pea defensins: gene expression pattern and evidence of broad host-range antifungal activity. Plant Sci 2002, 163:855-864.

45. Jayakumar P, Gossen BD, Gan YT, Wankentin TD, Banniza S: Ascochyta blight of chickpea: infection and host resistance mechanisms. Can J Plant Pathol 2005, 27:499-509.

46. Marrs KA: The functions and regulation of glutathione S-transferases in plants. Annu Rev Plant Physiol Plant Mol Biol 1996, 47:127-158.

47. Theodoulou FL: Plant ABC transporters. Biochim Biophys Acta 2000, 1465:79-103. 
48. Yazaki $K$ : $A B C$ transporters involved in the transport of plant secondary metabolites. FEBS Letters 2006, 580:1183-1191.

49. Hagihara T, Hashi M, Takeuchi Y, Yamaoka N: Cloning of soybean genes induced during hypersensitive cell death caused by syringolide elicitor. Planta 2004, 218:1432-2048.

50. Toyoda K, Miki K, Ichinose Y, Yamada T, Shiraishi T: Plants lectins induce the production of phytoalexin in Pisum sativum. Plant Cell Physiol 1995, 36(5):799-807.

51. Coram TE, Pang ECK: Transcriptional profiling of chickpea genes differentially regulated by salicylic acid, methyl jasmonate and aminocyclopropane carboxylic acid to reveal pathways of defenserelated gene regulation. Func Plant Biol 2007, 34:52-64.

52. Grant M, Mansfield J: Early events in host-pathogen interactions. Curr Opin Plant Biol 2007, 2:312-319.

53. Glazebrook J: Contrasting mechanisms of defense against biotrophic and necrotrophic pathogens. Annu Rev Phytopathol 2005, 43:205-227.

54. Curto M, Camafeita E, Lopez JA, Maldonado AM, Rubiales D, Jorrín V: A proteomic approach to study pea (Pisum sativum) responses to powdery mildew (Erysiphe pisi). Proteomics 2006, 6:163-174.

55. Die JV, Dita MA, Krajinski F, González-Verdejo Cl, Rubiales D, Moreno MT, Román B: Identification by suppression subtractive hybridization and expression analysis of Medicago truncatula putative defense genes in response to Orobanche crenata parasitization. Physiol Mol Plant Pathol 2007, 70:49-59.

56. Hammond-Kosack KE, Jones JDG: Plant disease resistance genes. Annu Rev Plant Physiol Plant Mol Biol 1997, 48:575-607.

57. Küster H, Hohnjec N, Krajinski F, El Yahyaoui F, Manthey K, Gouzy J, Dondrup M, Meyer F, Kalinowski J, Brechenmacher L, van Tuinen D, Gianinazzi-Pearson V, Pühler A, Gamas P, Becker A: Construction and validation of CDNA-based Mt6k-RIT macro- and microarrays to explore root endosymbioses in the model legume Medicago truncatula. J Biotech 2004, 108:95-113.

58. Hohnjec N, Vieweg MF, Phuler A, Becker A, Kuster H: Overlaps in the transcriptional profiles of Medicago truncatula roots inoculated with two different glomus fungi provide insights into the genetic program activated during arbuscular mycorriza. Plant Physiol 2005, 137:1283-1301.

59. Dondrup M, Goesmann A, Bartels D, Kalinowski J, Krause L, Linke B, Rupp O, Sczyrba A, Puhler A, Meyer F: EMMA: a platform for consistent storage and efficient analysis of microarray data. J Biotech 2003, 106:135-146.

60. Die JV, Román B, Nadal S, González-Verdejo Cl: Evaluation of candidate reference genes for expression studies in Pisum sativum under different experimental conditions. Planta 2010, 232:145-153.

doi:10.1186/1471-2164-12-28

Cite this article as: Fondevilla et al:: Identification of genes differentially expressed in a resistant reaction to Mycosphaerella pinodes in pea using microarray technology. BMC Genomics 2011 12:28.

\section{Submit your next manuscript to BioMed Central and take full advantage of:}

- Convenient online submission

- Thorough peer review

- No space constraints or color figure charges

- Immediate publication on acceptance

- Inclusion in PubMed, CAS, Scopus and Google Scholar

- Research which is freely available for redistribution

Submit your manuscript at www.biomedcentral.com/submit
Biomed Central 